Wojciech Engelking (Waszawa)

\title{
Recepcja myśli Carla Schmitta w USA po 1945 r*.
}

\section{WPROWADZENIE I UWAGI METODOLOGICZNE}

Kiedy w 1983 r. niemiecki socjolog Helmut Schelsky twierdził, że Carla Schmitta spotka w XXI wieku i stuleciach następnych los podobny do tego, który był udziałem Machiavellego i Hobbesa - długie zapomnienie, by jego twórczość mogła zostać odkryta dopiero po latach - mylił się ${ }^{1}$. Od prawie trzech dekad mamy bowiem do czynienia z renesansem myśli autora Teologii politycznej, przez wielu badaczy uważanej za najwłaściwszy pryzmat do analizy polityki zagranicznej i wewnętrznej trzech ostatnich amerykańskich prezydentów. Celem niniejszej pracy jest udowodnienie, iż źródła tej popularności leżą w adaptacji myśli Schmitta przez dwóch jego uczniów, którzy do USA wyemigrowali w latach 30.: Leo Straussa i Hansa Morgenthau, jak również przez myślicieli lewicowych, dla których Stany Zjednoczone były główną przestrzenią intelektualnego działania.

Pobieżne nawet przejrzenie najnowszej literatury potwierdza tezę o tym, iż amerykańscy myśliciele chętnie używają Schmitta do odczytywania poczynań George'a W. Busha, Baracka Obamy i Donalda J. Trumpa. Jeśli chodzi o pierwszego, to, jak uważa Jason Ralph, nie trzeba długo się zastanawiać, by dojść do wniosku, że wypracowana przez Schmitta koncepcja stanu wyjątkowego może pomóc $\mathrm{w}$ interpretacji postępowań jego administracji w odpowiedzi na zagrożenie ze strony Al Kaidy². Myśl Ralpha uściślają tacy politologowie, jak Clayton Crockett

* Artykuł powstał w ramach grantu „Diamentowy Grant” Ministerstwa Nauki i Szkolnictwa Wyższego (Projekt nr rej. DI2014 000544 pt. „Stan nadzwyczajny jako model absolutny w myśli filozoficzno-prawnej Carla Schmitta. Aktualność koncepcji i jej pragmatyczna krytyka").

${ }^{1}$ Zob.: C.-G. Heidegren, Transcendental Theory of Society, Anthropology and the Sociology of Law. Helmut Schelsky: An Almost Forgotten Sociologist, „Acta Sociologica” 1997, Vol. 40, No. 3, s. 287.

2 J. Ralph, The laws of war and the state of the American exception, „Review of International Studies" 2009, 35, s. 631. 
(widzący w uchwalonym w 2006 r. Military Comissions Act, który dawał prezydentowi prawo do definiowania, kto jest wrogiem państwowym bez zwracania uwagi na treść konwencji genewskich czy decyzję sądu, wyraz myślenia o prawie państwowym, jaki Schmitt proponuje w Teologii politycznej ${ }^{3}$ ), Christopher Kurtz

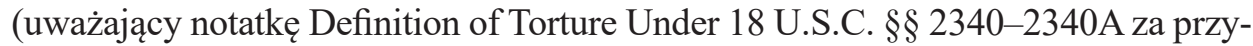
kład zawieszenia obowiązywania podstawowych praw obywatelskich na skutek radykalizacji uprawnień egzekutywy w obliczu konieczności zdefiniowanej tak, jak proponował to Schmitt ${ }^{4}$ ) czy Thomas Durkin (który określił Terrorist Surveillance Act i Foreign Intelligence Surveillance Act jako permanentny stan wyjątkowy w rozumieniu Carla Schmitta ${ }^{5}$.

Ponieważ, jak uważa Jack Goldsmisth, zwłaszcza zagraniczna polityka Baracka Obamy była w dużej mierze kontynuacją Bushowej, i w niej łatwo dają się odszukać Schmittiańskie naleciałości ${ }^{6}$. Oczywiście, można uznać - jak proponują niektórzy badacze $^{7}$ - że 44. prezydent USA wskazówki Schmitta wykorzystał przez ich odwrócenie: wykorzystanie przez odwrócenie również jest jednak wykorzystaniem. Jeżeli chodzi o prezydenturę Donalda J. Trumpa, już w drugim roku jego panowania w Białym Domu wydana została praca, w której jeden z autorów określa jego styl rządzenia decyzjonistycznym i wykorzystującym koncepcję stanu wyjątkowego w formie, w jakiej wypracował ją Carl Schmitt ${ }^{8}$. Ów metodologiczny trend skomentował pod koniec poprzedniej dekady Tomasz Gabiś, stwierdzając, iż pośmiertnie autor Pojęcia polityczności awansował przynajmniej w popularnej wyobraźni z koronnego jurysty III Rzeszy na „koronnego jurystę prezydenta Stanów Zjednoczonych! Zaiste, zostać koronnym jurystą przywódcy imperium światowego, o takiej karierze mędrzec z Plettenbergu nie marzył chyba w najśmielszych snach" . Pisząc o tej popularności dzisiaj, w jedenaście lat po opublikowaniu przez Gabisia cyto-

3 C. Crockett, Radical Political Theology: Religion and Politics After Liberalism, New York 2013, s. $109-110$.

${ }^{4}$ C. Kurtz, Torture, Necessity and Existential Politics, „California Law Review” 2007, 235, s. 238.

5 T. Durkin, Permanent States of Exception: A Two-Tiered System of Criminal Justice Courtesy of the Double Government Wars on Crime, Drugs \& Terror, „Valparaiso Law Review” 2016, 419, s. 461.

${ }^{6}$ Zob.: J. Goldsmith, Power and Constraint: The Accountable Presidency after 9/11, New York 2012, s. 25. Należy tu też wspomnieć o uwadze Howarda Zinna, który przypomina, iż wojna z terroryzem prowadzona przez Busha spotkała się, w początkowym przynajmniej okresie, z wielkim poparciem Partii Demokratycznej. Zob.: H. Zinn, Ludowa historia Stanów Zjednoczonych. Od roku 1492 do dziś, przeł. A. Wojtasik, Warszawa 2016, s. 938.

${ }^{7}$ Por. E. Fairhead, Carl Schmitt's politics in the age of drone strikes: examining the Schmittian texture of Obama's enemy, „Journal of Cultural Research” 2018, Vol. 22, s. 39-54.

${ }^{8}$ F. Mohamed, „I Alone Can Solve”. Carl Schmitt on Sovereignity and Nationhood under Trump, [w:] A.J. Torres, M.B. Sable (red.), Trump and Political Philosophy. Leadership, Statemanship and Tyranny, New York 2018, s. 300-301.

9 T. Gabiś, Carl Schmitt, „Nowe Państwo” 2007, nr 3. 
wanego komentarza, można pokusić się o jego redakcyjną korektę: nie „prezydenta Stanów Zjednoczonych”, lecz „prezydentów”.

Tego rodzaju popularność myśli Schmitta jako pryzmatu, przez który dzisiejsi myśliciele i komentatorzy polityczni odczytują wydarzenia we współczesnych Stanach Zjednoczonych, jest symptomatyczna z co najmniej kilku powodów. Po pierwsze: sam Schmitt uważał swoją filozofię polityczną za mniej lub bardziej zakorzenioną w czasach, w których przyszło mu żyć ${ }^{10}$. Po drugie: USA jawią się jako ostatnie państwo, które Schmitt uważałby za wymarzone miejsce do adaptacji swojej koncepcji. Wśród niemieckich rewolucyjnych konserwatystów w latach 20. XX w. (z którym to nurtem polityczno-ideowym często Schmitta konotowano) Ameryka była symbolem wszystkiego, co najgorsze, to zaś, co przedstawiciele tego środowiska określali jako Amerikanismus, czyli „masowa produkcja i konsumpcja, tayloryzm, racjonalizacja przemysłu, stanowiło według nich plagę zatruwającą niemieckie dusze"11. I choć Schmitt nie był w krytyce USA tak radykalny, jak inni rewolucyjni konserwatyści, Ameryka i jej system polityczny były dlań pod względem jurydycznym po prostu nieefektywne; w Duchowej $i$ historycznej sytuacji dzisiejszego parlamentaryzmu z 1923 r. wskazuje na USA jako przykład państwa antydecyzjonistycznego, w którym rządzą nie ludzie, lecz prawa $^{12}$. Po trzecie: w USA nigdy nie dokonał się proces denazyfikacji Schmitta, jaki był jego udziałem w Europie.

Jak twierdzi Alain de Benoist, powszechne wyobrażenie na temat filozofa z Plettenbergu i wpływu jego myśli na ideowe założenia polityki amerykańskiej w ostatnich dwóch dekadach stanowi zatem, iż ustawodawstwo amerykańskie żywi się autorem Teologii politycznej jako tym myślicielem, który ufundował ideowe podstawy dla ideologii nazistowskiej: w Stanach Zjednoczonych dominuje aktualnie „ogólna idea, w ramach której Schmitt był faszystą, Leo Strauss propagował idee nazistowskie w Ameryce, administracja Busha z kolei, inspirująca się myślą Straussa, potraktowała ją jako pośredniczącą do idei Schmitta i do nazizmu. Ta groteskowa teza wielokrotnie towarzyszyła spiskowemu odczytaniu myśli Leo Straussa"13. Takie spojrzenie na Schmitta nie ciąży wyłącznie nad wy-

${ }^{10}$, „...) działalność naukowa uprawiającego prawo publiczne sytuuje go w określonym kraju, w obrębie określonych środowisk i sił, w określonym kontekście czasowym, wiąże go z sytuacjami politycznymi”. C. Schmitt, Ex Captivitate Salus, przeł. A. Kluba, „Przegląd Polityczny” 2014, nr 127/128, s. 68.

${ }^{11}$ J. Herf, Reactionary Modernism: Technology, Culture, and Politics in Weimar and the Third Reich, Cambridge 1986, s. 42.

${ }^{12}$ C. Schmitt, Duchowa i historyczna sytuacja dzisiejszego parlamentaryzmu, [w:] C. Schmitt, Teologia polityczna i inne pisma, przeł. M.A. Cichocki, Warszawa 2012, s. 192-193.

13 A. de Benoist, Carl Schmitt today. Terrorism, ,just” war, and the state of emergency, przeł. A. Jacob, London 2013, s. 11. Oczywiście, polityczne zaangażowanie de Benoista każe jego prace traktować ze szczególną ostrożnością. 
obraźnią popularną, lecz także naukową: przykładowo, w ogłoszonym w 2008 r. na łamach „Miami Law Review” artykule David Abraham, badacz prawa publicznego z Uniwersytetu w Miami, wywodząc z myśli Schmitta sposób, w jaki administracja George'a W. Busha prowadziła tzw. „wojnę z terrorem”, wprost określa ustawę w popularny sposób nazywaną PATRIOT Act mianem amerykańskiej wersji Ermächtigungsgesetz ${ }^{14}$.

By udowodnić, iż myśl Schmitta do USA trafiła za sprawą Leo Straussa i Hansa Morgenthau, spośród licznych współczesnych koncepcji dotyczących zjawiska transferu pojęć poza obręb dyscypliny czy kraju pochodzenia, na podstawę metodologiczną wybrałem koncepcję Mieke Bal. Badaczka koncentruje się wprawdzie na transferze pojęć pomiędzy dyscyplinami naukowymi, nie zaś pomiędzy uczonymi czy obszarami geograficznymi ${ }^{15}$, jednak jej koncepcja wydaje mi się o tyle właściwa, że Bal silnie podkreśla szczególną przyczynę takiego transferu: wyjątkową adekwatność transponowanego pojęcia do opisu danej sytuacji. Zdaniem Bal, pojęcia „organizują grupę zjawisk, definiują pytania, które można zadać i określają znaczenia, które należy nadać obserwacjom dotyczącym zjawisk”, są pojęciami żywymi wyłącznie wówczas, kiedy ich „adekwatność zostanie zagwarantowana, a zatem uznana. Pojęcie - zaznacza Bal - musi być uznane za adekwatne. Adekwatność ta nie jest »realistyczna« - nie chodzi o prawdziwość reprezentacji"16. Takimi pojęciami, pochodzącymi z teorii polityki Schmitta, stały się w ciągu ostatnich dekad w USA ,polityczność”, „stan wyjątkowy” i ,decyzjoznim”.

Pojęcia, których wędrówkę opisuje Mieke Bal, nie są ideami, które mogłyby być $\mathrm{w}$ prawodawstwie amerykańskim ujęte w przepisy i normy, ale pewnego rodzaju pryzmatem, przez który postrzegane $\mathrm{i}$ interpretowane są działania prawne i polityczne. Jednocześnie to trudne do zdefiniowania pojęcie, obejmujące zakres szerszy niż jedna, konsekwentnie zbudowana i będąca częścią spójnej teorii idea, obliczone jest na wywołanie kontrowersji: „podstawowa funkcja pojęć - pisze niderlandzka badaczka - to niepozostawianie człowieka obojętnym, zmuszanie go do zaangażowania i zajęcia stanowiska"17. Popularność pojęć Schmitta jako pryzmatu, przez który badacze (i nie tylko) postrzegają działania w wewnętrznej i zewnętrznej polityce USA i gorące spory, jakie ta ostatnia za sprawą właśnie

${ }_{14}$ D. Abraham, The Bush Regime from Elections to Detentions: A Moral Economy of Carl Schmitt and Human Rights, „University of Miami Law Review” 249 (2008), s. 258.

${ }^{15}$ Choć twierdzi, że pojęcia mogą być transponowane „pomiędzy dyscyplinami i między poszczególnymi uczonymi, między okresami historycznymi i między rozproszonymi geograficznie społecznościami uczonych. M. Bal, Wędrujace pojęcia w naukach humanistycznych. Krótki przewodnik, przeł. M. Bucholc, Warszawa 2012, s. 49.

${ }^{16}$ M. Bal, Wędrujące pojęcia..., s. 57.

${ }^{17}$ M. Bal, Wędrujące pojęcia..., s. 56. 
pojęć Schmitta budzi, z pewnością pokazuje, że spełniają one stawiane przez Bal pod względem kontrowersyjnego charakteru wymagania. Podobnie jest z innymi, wymienionymi przez niderlandzką badaczkę: i „stan wyjątkowy”, i „,polityczność”, i „decyzjonizm” posiadają swoją historię, są „słowami wystrzeliwanymi jako zupełnie zwariowane ćwiczenia etymologiczne, dające wyobrażenie o filozoficznym »smaku«, są też „nieprzerwanie zmienne i (...) tworzone, nie dane" ${ }^{18}$. W niniejszej pracy interesował mnie będzie ów aspekt zmienności i tworzenia oraz to, jak doprowadził on do tego, że obraz Schmitta wygląda w USA tak, jak opisał go Alain de Benoist.

Jest to o tyle interesujący problem, że obydwu myślicieli politycznych, za sprawą których myśl Schmitta trafiła, według mnie, do dyskursu politycznego w Stanach Zjednoczonych, trudno uznawać za przedstawicieli radykalnej prawicy. Na najbliższych stronach przedstawię toteż, w jaki sposób Leo Strauss, jak i Hans Morgenthau umieścili pojęcia pochodzące z myśli Schmitta w amerykańskim dyskursie politycznym. By sytuację skomplikować, zaprezentuję również innych amerykańskich pogrobowców autora Pojęcia polityczności: autorów skupionych wokół lewicowego pisma „Telos”. Są to postaci różne rangą na mapie historii myśli politycznej w XX w., wszystkie jednak, jak sądzę, w istotnym stopniu przyczyniły się do popularności autora Teologii politycznej w Stanach Zjednoczonych. Interesuje mnie zastosowanie pojęć Schmitta do polityki amerykańskiej, nie jego wpływ amerykańskie ustawodawstwo początku XXI w.

\section{SCHMITT PO 1945 R. W EUROPIE}

Wyjątkowy charakter popularności Schmitta w USA najlepiej widoczny będzie, gdy ukaże się go w kontraście do historii odbioru jego teorii politycznej w powojennej Europie - w której zresztą odbyło się pierwsze spotkanie Schmitta $\mathrm{z}$ amerykańskim systemem politycznym w osobie jego funkcjonariusza. Okoliczności trudno uznać za sprzyjające: od sierpnia 1945 r. do marca 1947 r. autor Pojęcia polityczności przebywał w kilku obozach internowania jako podejrzany o popełnienie zbrodni wojennych. W październiku 1945 r. odbyło się jego pierwsze przesłuchanie. Prokuratorem, który został doń wyznaczony, był Robert Kempner, zastępca Roberta Jacksona, głównego prokuratora USA podczas procesów norymberskich i niemiecki emigrant, który III Rzeszę opuścił w roku 1938 i od 1939 r. pełnił funkcję specjalnego doradcy prezydenta Roosevelta ${ }^{19}$. Kempner, jak wskazuje Michael G. Salter, był również przyjacielem Franza Neumanna, dawnego studenta Schmitta pochodzenia żydowskiego, który po 1933 r. wyjechał

\footnotetext{
${ }^{18}$ Ibidem, s. 77.

19 Zob.: J. Bendersky, Carl Schmitt at Nuremberg, „Telos” 1987, 72, s. 91.
} 
z Niemiec do USA. W tych ostatnich opublikował w 1943 r. pracę pt. Behemot, w której Schmitt funkcjonuje dwojako: po pierwsze jest źródłem wielu Neumannowych idei i pomysłów, po drugie - jest głównym Behemota szwarccharakterem. To właśnie ten tekst, uważa Salter, „był odpowiedzialny za obraz Schmitta w oczach sił amerykańskich, w tym zespołu prokuratorów w Norymberze" 20 .

Zasadniczym celem Kempnera w przesłuchaniu Schmitta było dowiedzenie, że uczestniczył on w zbrodniach przeciwko ludzkości. Amerykański prokurator prowadził przesłuchanie, zmuszając autora Pojęcia polityczności do odpowiadania wyłącznie „tak” lub „nie”. Pragnął odkryć rzekome powiązanie pomiędzy pracą Schmitta jako prawnika zajmującego się prawem konstytucyjnym a działalnością Hansa Lammersa (doradcy prawnego Hitlera, skazanego w Norymberze na dwadzieścia lat więzienia). Schmitt takim powiązaniom zaprzeczył, stwierdzając, iż chociaż $\mathrm{w}$ istocie był jedną $\mathrm{z}$ uniwersyteckich sław w III Rzeszy, nie spotykał się z żadnymi politycznymi ani partyjnymi oficjelami. Ponadto, dodał, już w przeszłości korespondował ze znanym genewskim prawnikiem i pacyfistą, Ottonem Wehbergiem, i jego praca pomogła w stworzeniu legalnej definicji zbrodni wojennej. Na poczynioną w Behemocie Neumanna i przypomnianą przez Kempnera uwagę, jakoby Schmittiańska teoria większego obszaru była intelektualną podbudową dla programu Lebensraum, odparł, że niemieccy politycy raczej lekceważyli jego dzieła. Jak podsumowuje cytowany już Salter, „Schmitt nie zaprzeczał swojej pozycji uniwersyteckiej, zaprzeczał jednak, by taka pozycja miała wpływ na działanie państwa" ${ }^{21}$.

Odpowiedzi udzielane przez Schmitta Kempnerowi, chociaż mogą się zdawać zmyślną grą autora Pojęcia polityczności z amerykańskim prokuratorem, wcale nie musiały być nieszczere. Jak uważa Jürgen Habermas, tacy niemieccy intelektualiści, którzy na początku lat 30. udzielali poparcia reżimowi nazistowskiemu, jak Schmitt czy Heidegger, „po 1945 r. uważali, że nie mają czego żałować. Uznawali, że ruch, którego stronnikami byli w 1933 r., później ich zawiódł"22. Schmitt swoimi szczerymi odpowiedziami się toteż z oskarżeń Kempnera wykaraskał; nie zaszkodziła mu także opinia na jego temat, którą napisał dla American Office of Strategic Services (OSS) Karl Loewenstein, stwierdzając, iż zaangażowanie autora Pojęcia polityczności w nazizm było czysto oportunistyczne, a „profesor Schmitt potrafił być tak samo był zręcznym i zagorzałym obrońcą demokracji,

${ }^{20}$ M.G. Salter, Neo-Fascist Legal Theory on Trial: An Interpretation of Carl Schmitt's Defence at Nuremberg from the Perspective of Franz Neumann's Critical Theory of Law, „Res Publica” 1999, 5, s. 175-176.

${ }^{21}$ M.G. Salter, Neo-Fascist Legal Theory on Trial, s. 179.

22 J. Habermas, A Berlin Republic: Writings on Germany, przeł. S. Rendall, Lincoln 1997, s. $116-117$. 
jak również obrońcą totalitaryzmu"23. Wskazywany przez Habermasa brak poczucia, że współuczestniczył w działaniach nazistów sprawił, że Schmitt odmówił udziału w denazyfikacji - co uniemożliwiło mu otrzymanie po 1945 r. członkostwa w Związku Niemieckich Prawników, a także zamknęło drogę kariery akademickiej. I chociaż dzięki swoim dawnym uczniom, którzy poczęli robić karierę w RFN, nie musiał się Schmitt martwić o kwestie finansowe - otrzymał dożywotnią rentę i wrócił do rodzinnego domu w Plettenbergu (nazwał go San Casciano, od wioski w Toskanii, w której wygnanie spędzał Machiavelli) - to zdawałoby się, że jego wpływ i na debatę publiczną, i na filozofię polityczną jest skończony.

Można by przypuszczać, że po wojnie Schmitt jako filozof całkowicie straci wpływ na światowy dyskurs również z powodu atmosfery politycznej i ideowej, jaka zapanowała w świecie Zachodu po 1945 r. i utrzymywała się aż do roku 1968. Była to, jak twierdzi Alan Wolfe, epoka bezgranicznego nieomal panowania liberalizmu. Myślenie o polityce na sposób liberalny wydawało się wówczas „całkowicie konsensualne, konserwatyzm z kolei wydawał się nieistniejącym, podobnie jak ideologia, która była martwą, a historia skończoną"24. W USA dwie główne partie znacząco się do siebie upodobniły (w latach 50. prezydent Eisenhower zgodnie pracował z Demokratami nad kolejnymi ustawami), podobnie było w Wielkiej Brytanii; co prawda zdarzały się wewnętrzne napięcia, niewiele jednak sygnałów o konflikcie trafiało do opinii publicznej25. Ujmując rzecz słowami Habermasa, w latach 50. zdawało się, że wiktoria aliantów „na dobre zdyskredytowała zbiór mitów, które od końca XIX stulecia mobilizowały ludzi przeciwko dziedzictwu roku 1789"26. W takich warunkach liberalnej hegemonii ideom Carla Schmitta trudno było zyskać masowego odbiorcę; jeżeli bowiem, twierdził Reinhard Mehring, coś wiąże wszystkie dzieła z bogatej spuścizny (i pod względem poruszanych wątków, i pod względem rozmiaru) autora Rzymskiego katolicyzmu i politycznej formy, to tym czymś jest właśnie niechęć wobec liberalizmu ${ }^{27}$.

Nie znaczy to, że Schmitt stał się w latach 50. i na początku 60. filozofem całkiem zapomnianym: wciąż utrzymywał korespondencję z tuzami zachodniego życia intelektualnego, których przyjmował w swoim domu w Plettenbergu (m.in. Alexandrem Kojèvem, robiącym wówczas wielką karierę we francuskiej administracji, czy

${ }^{23}$ K. Loewenstein, Observations on Personality and Work of Professor Carl Schmitt, tekst niepublikowany, dostępny w archiwum K. Loewensteina złożonym w Amherst College (Amherst, MAS, USA), cyt. za: O.A. Hathaway, S.J. Shapiro, The Internationalists. How a Radical Plan to Outlaw War Remade the World, New York 2017, s. 292.

${ }^{24}$ A. Wolfe, The Future of Liberalism, New York 2009, s. 137.

${ }^{25}$ Ibidem, s. 144.

26 J. Habermas, The Postnational Constellation: Political Essays, przeł. Max Pensky, Cambridge 2001, s. 46.

${ }^{27}$ R. Mehring, Liberalism as a »Metaphysical System «, [w:] D. Dyzenhaus (red.), Law as Politics. Carl Schmitt's Critique of Liberalism, Durham-London 1998, s. 134. 
Jacobem Taubesem). Wpływy jego dawnych uczniów w RFN, zarówno polityczne, jak i naukowe, umożliwiły jeśli nie przedostanie się jego myśli do mainstreamowego dyskursu, to, jak pisze Christian Linder - „stworzenie subwersywnego nurtu w historii intelektualnej RFN-u"28. To wszystko odbywało się jednak w Niemczech, za granicą Schmitt był znany słabo: trochę we frankistowskiej Hiszpanii, trochę też we Włoszech, według niektórych badaczy da się też zauważyć jego wpływ na politykę Charlesa de Gaulle'a i, co może zdawać się paradoksalne - na uchwalane od 1948 r. do 1960 r. dokumenty składające się na konstytucję państwa Izrael. Trudno to jednak uznać za popularność masową - nawet w tym rozumieniu masowości, jakie może stać się udziałem teoretyka polityki.

Po dwóch z trzech powojennych „dekad glorii” nadszedł jednak rok 1968 i przemiany kulturowe w Europie wpłynęły na zmianę klimatu intelektualnego ${ }^{29}$. Zmiana ta nie musiała być dla Schmitta łaskwa - jak przypomina Roger Scruton, protesty tamtego roku wynikały $\mathrm{z}$ silnych inspiracji ideami zawartymi $\mathrm{w}$ dziełach myślicieli lewicowych ${ }^{30}$. To właśnie w 1968 r. młody, powiązany z prawicą francuski filozof Alain de Benoist założył jednak ruch GRECE (Groupement de recherche et d'études pour la civilisation européenne), w którego manifeście, napisanym przez de Benoista wraz z Charlesem Champetierem, łatwo usłyszeć echo wielu kluczowych dla Carla Schmitta idei. „Państwo liberalne - pisali de Benoist i Champetier - zbyt często staje się synonimem republiki sędziów, i skupia się (...) na neutralizowaniu konfliktów wpisanych w różnorodność życia społecznego. Czyni to przez wprowadzanie polityk skupionych na determinowaniu, przez jurydyczne procedury, tego, co jest sprawiedliwe miast tego, co jest dobre" 31 . Według przedstawicieli francuskiego ruchu (który wkrótce po ogłoszeniu tego manifestu zyskał miano nouvelle droite), pisał uczeń i komentator de Benoista, chorwacki filozof Tomislav Sunić, liberalizm przestał być nurtem ideologicznym, lecz stał się globalnym systemem opartym na hipermodernizmie i ideologii praw człowieka; i chociaż niepodzielnie panuje, w ekonomicznych, politycznych i moralnych wymiarach jego formuła się jednak wyczerpała ${ }^{32}$. Oznaką, że filozofowie ci nie mylili się co do wyczerpania liberalizmu, może zdawać się fakt, że schmittiańskie z ducha teksty de Benoista publikowane były nie tylko w radykalnych periodykach intelektualnych („Mankind Quarterly”, „Chronicles”), ale

${ }^{28}$ C. Linder, Carl Schmitt in Plettenberg, [w:] O. Simmons, J. Meierhenrich (red.), The Oxford Handbook of Carl Schmitt,, Oxford 2016, s. 159.

${ }^{29}$ Zob.: J.-W. Müller, A Dangerous Mind. Carl Schmitt in Post-War European Thought, New Haven 2003, s. 59, 209.

${ }^{30}$ R. Scruton, Fools, frauds and firebrands: thinkers of the New Left, London 2015, s. 108.

${ }^{31}$ A. de Benoist, C. Champetier, Manifesto for a European Renaissance, London 2012, s. $15-16$.

${ }^{32}$ T. Sunić, Against Democracy and Equality: The European New Right, London 2011, s. 214. 
też wysokonakładowych gazetach codziennych („Le Figaro”), a w 1978 r. de Benoist otrzymał nagrodę Akademii Francuskiej w dziedzinie eseju. Oczywiście, piśmiennictwo de Benoista spotkało się też z szeroko zakrojoną krytyką, i to nie tylko we Francji. Thomas Sheenan, dla przykładu, uznał je za próbę restauracji faszyzmu w powojennym świecie ${ }^{33}$. Podobnie niechętny de Benoistowi był Roger Griffin, który pisał, iż myśliciele z kręgu francuskiej Nowej Prawicy udają nieskażonych ideologią metapolityków, by pokątnie podsunąć czytelnikowi kryptofaszystowskie elementy ${ }^{34}$.

Francja nie była jedynym krajem, w którym po roku 1968 zainteresowana ideami Carla Schmitta prawica doszła do głosu ${ }^{35}$. W Niemczech w 1986 r. założono tygodnik Junge Freiheit, który kultywował schmittiański decyzjonizm; we Włoszech Gianfranco Miglio, politolog i filozof, inspirator Ligi Północnej, promował idee myśliciela z Plettenbergu wśród inteligencji najmłodszego pokolenia. Jak pisze Alan Wolfe, po 1968 r. ,dla jakiegokolwiek intelektualisty przekonanego, że nowoczesność nie jest najlepszym z możliwych wyborów wyprawa do Plettenbergu czy wymiana listów z mędrcem anty-liberalizmu stała się rite de passage"36. Owa niechęć do nowoczesności, warto zaznaczyć, nie musiała być związana z prawą stroną sceny politycznej. W $1968 \mathrm{r}$. argumentami z gruntu schmittiańskimi przeciw liberalizmowi posługiwał się Johannes Agnoli, nazwany przez Jana-Wernera Müllera intelektualnym architektem roku 1968; na początku lat 70. z kolei niemiecki filozof określający się jako maoista, Joachim Schickel, twierdził, iż jeden jedyny Schmitt jest na europejskiej scenie intelektualnej myślicielem, który ma cokolwiek do powiedzenia na temat walk partyzanckich. Swoją wizję miejskiej partyzantki późniejsi terroryści Andreas Baader i Ulrike Meinhof promowali schmittiańskim z ducha sloganem o potrzebie oddzielenia siebie od (w domyśle: liberalnego i prawicowego) wroga ${ }^{37}$. We Włoszech istnieli nawet schmittiańscy marsksiści (skupieni wokół pisma „Quaderni rossi”). Nie trzeba w tym miejscu dodawać, że Schmitt, choć obciążony anatemą myśliciela, który nie oczyścił się z nazizmu, wciąż był publikowany w oficjalnych, dużych domach wydawniczych - i nie były to tylko prace nowe, ale też wznowienia tych, które wydawał w latach 20. i 30. XX wieku.

${ }^{33}$ T. Sheenan, Myth and Violence: The Fascism of Julius Evola and Alain de Benoist, „Social Research" 1981, 48, s. 66-67.

${ }^{34}$ R. Griffin, Between metapolitics and apoliteia: the Nouvelle Droite's strategy for conserving the fascist vision in the ,,interregnum”, „Modern \& Contemporary France” 2000, 8, s. 35-53.

${ }^{35}$ Monserrat Herrero nazywa okres powojennej recepcji myśli Schmitta „bezpieczeństwem milczenia”. M. Herrero, The Political Discourse of Carl Schmitt, London-New York 2015, s. 10.

${ }^{36}$ A. Wolfe, The Future of Liberalism, s. 138.

${ }^{37}$ Zob.: J.-W. Müller, A Dangerous Mind. Carl Schmitt in Post-War European Thought, s. 146, 171. 
Śmierć filozofa z Plettenbergu w Wielki Piątek 1985 r. nie spowodowała, że przestał budzić zainteresowanie i kontrowersje. Co interesujące, nawet nekrolog Schmitta, napisany przez Kurta Sontheimera w dzienniku „Die Zeit”, zawierał krytykę jego filozofii (Sontheimer stwierdził w nim, iż komu zależy na liberalnej demokracji, ten nie potrzebuje Carla Schmitta) ${ }^{38}$. W tym samym czasie schmittiańskie naleciałości w krytyce liberalnej demokracji autorstwa Habermasa odnalazła Brytyjka Ellen Kennedy, a pracę o długim dialogu Schmitta i Leo Straussa opublikował Heinrich Meyer. Wprost uznała Schmittiańską kategorię polityczności za przydatną dla lewicy na początku lat 90 . belgijska myślicielka Chantal Mouffe ${ }^{39}$. Schmittiańskim rozróżnieniem na przyjaciela i wroga posługiwał się, zdaniem Jana-Wernera Müllera, Samuel Huntington w swoim słynnym dziele o wojnie cywilizacji (skądinąd jego spór z Francisem Fukuyamą był jakby kontynuacją sporu Schmitta z mistrzem tego Fukuyamy, Kojèvem) ${ }^{40}$. Ze Schmitta (połączonego, jak przypomina Timothy Snyder, z Iwanem Iljinem, który również się Schmittem inspirował) czerpał i wciąż czerpie również rosyjski filozof i wpływowy współcześnie ideolog geopolityczny, Aleksandr Dugin ${ }^{41}$. Jak podsumowywał dwie dekady temu ów europejski renesans cytowany już Gabiś, w Europie „tylko w latach 1996-2002 ukazało się 85 książek na jego [Schmitta] temat - jedna na miesiąc, poza tym powódź artykułów, rozpraw, dysertacji" ${ }^{\prime 2}$. Oczywiście - jak wskazywał w 1987 r. Jacob Taubes - ilość nie musi przekładać się na jakość, a duża część prac na temat Schmitta, jakie powstały w latach 70. i 80. krajach niemieckojęzycznych miała za zadanie go zdyskredytować i zagłuszyć; przez pewien czas, zdaniem Taubesa, europejski klimat intelektualny pozwalał też, by „byle jaki docent politologii mógł sobie Carla Schmitta (i/lub Karola Marksa) kopnąć w swoim wykładzie inauguracyjnym"43.

W USA było inaczej niż na Starym Kontynencie. W powojennej Europie idee Schmitta dość szybko znalazły wyznawców w nowym pokoleniu intelektualistów o poglądach konserwatywnych, chociaż nikt ich tam nie promował. W Stanach Zjednoczonych miały, początkowo przynajmniej, propagatorów starszych (acz odrobinę od Schmitta młodszych), z których żaden nie był byle jakim docentem politologii.

${ }^{38}$ K. Sontheimer, Der Macht näher als dem Recht, „Die Zeit” z 19.04.1985, wersja online: https://www.zeit.de/1985/17/der-macht-naeher-als-dem-recht [dostęp: 17.11.2018].

39 J.-W. Müller, A Dangerous Mind. Carl Schmitt in Post-War European Thought, s. 221-222. Zob. także: Ch. Mouffe, Polityczność, przeł. J. Erbel, wstęp M. Gdula, Warszawa 2008.

40 J.-W. Müller, A Dangerous Mind. Carl Schmitt in Post-War European Thought, s. 240.

${ }^{41}$ T. Snyder, The Road to Unfreedom. Russia, Europe, America, New York 2018, s. 203 i następne.

${ }^{42}$ T. Gabiś, Carl Schmitt.

43 J. Taubes, Ad Carl Schmitt. Gegenstrebige Fügung, Berlin 1987, s. 76. 


\section{POLITYCZNOŚĆ MIĘDZYNARODOWA}

Zdaniem Mieke Bal, jeżeli dane pojęcie wędruje między uczonymi, grozi mu pewnego rodzaju wypaczenie poprzez wykorzystanie przez późniejszego uczonego do analizy zjawiska, dla którego pojęcie nie zostało stworzone ${ }^{44}$. Sytuację tę dobrze, jak sądzę, obrazuje historia przeniesienia na grunt amerykańskiej filozofii polityki pojęć teorii politycznej Carla Schmitta przez pierwszego z bohaterów niniejszej pracy - Hansa Morgenthau. Ów urodzony w 1904 r. w rodzinie aszkenazyjskich Żydów w Coburgu prawnik, wykształcony na uniwersytetach w Berlinie, Frankfurcie i Monachium, do USA przybył w roku 1937 (najpierw wykładał w Kansas, następnie zaś na Uniwersytecie w Chicago i Centralnym Uniwersytecie w Nowym Jorku) i od 1946 r. publikował wyłącznie po angielsku. W tym też języku napisał swoje podstawowe prace dotyczące teorii geopolityki i prawa międzynarodowego - Politykę między narodami z 1948 r., In Defense of the National Interest z 1951 r. i The Purpose of American Politics z roku 1960.

Rekonstrukcja podstawowych tez teorii geopolitycznej Morgenthau nie jest szczególnie trudna: późniejszy doradca prezydenta Kennedy’ego sam przedstawił je w sześciu zasadach realizmu politycznego, otwierających drugie, opublikowane w latach 50., wydanie jego Polityki między narodami. Jak słusznie zauważa Andrzej Gałganek, należy zwrócić szczególną uwagę na to, czym owych sześć zasad jest poprzedzone - czyli wprowadzonym przez Morgenthau rozróżnieniem dwóch szkół myślenia o polityce. Realistycznej, z którą się identyfikuje, przeciwstawia Amerykanin drugą, która „wierzy, że racjonalny i moralny porządek polityczny, wyprowadzony z uniwersalnie prawomocnych abstrakcyjnych zasad, może być zrealizowany tu i teraz. Zakłada naturalną dobroć i plastyczność ludzkiej natury (...). Szkoła ta jest przekonana, że poprzez edukację, reformy i sporadyczne użycie siły można te niedostatki wyeliminować" ${ }^{45}$. Szkołę drugą opisuje sześć zasad, po pierwsze: polityka i społeczeństwo rządzą się obiektywnymi prawami, które są niezależne od woli człowieka, bowiem zakorzenione w jego naturze; po drugie: pojęciem centralnym dla polityki jest interes narodowy definiowany w kategoriach potęgi, który uniezależnia polityczność od innych sfer (ekonomii, religii); po trzecie: interes narodowy stanowi kategorię obiektywną, jednak nie jest wyposażony w ustalone raz na zawsze znaczenie; po czwarte: $\mathrm{w}$ realizmie politycznym obecna jest świadomość moralnej wagi działań politycznych; po piąte: żadne partykularne (ideologiczne) wartości lub jednostkowy interes narodowy nie

${ }^{44}$ M. Bal, Wędrujące pojęcia..., s. 24.

${ }^{45}$ A. Gałganek, Pierwsza ,wielka debata”? Rewizjonistyczna historia genezy teoretyzowania w nauce o stosunkach międzynarodowych, „Przegląd Strategiczny” 2017, 10, s. 30. 
mogą pretendować do miana uniwersalnych; po szóste: realizm polityczny zachowuje odrębność od innych szkół stosunków międzynarodowych ${ }^{46}$.

Myśląc o realistycznej teorii polityki Hansa Morgenthau z Polityki między narodami należy pamiętać, że zakorzeniona ona jest, jak wskazuje Robert Osgood, w jego pracy Scientific Man vs. Power Politics z 1946 roku. Dzieło to trudno zaliczyć stricte do dziedziny politologii; należałoby je raczej nazwać propozycją z jednej strony polemiczną, z drugiej zaś - metodologiczną. Owa pierwsza anglojęzyczna publikacja Morgenthau stanowi bowiem krytykę racjonalizmu, który, zdaniem późniejszego doradcy prezydenta Kennedy’ego, zaczął przejmować dyskurs w filozofii moralnej, społecznej i politycznej w świecie Zachodu ${ }^{47}$. Jest to przejmowanie o tyle szkodliwe dla dyskursu, że racjonalność, zdaniem Morgenthau, zawsze zostanie zmieciona przez wyższą od niej siłę. Morgenthau proponuje toteż, by studia nad polityką postrzegać jako sztukę, nie naukę, bowiem ich przedmiot nie może nigdy zostać zracjonalizowany ${ }^{48}$. I chociaż uwaga Morgenthau może zdawać się propozycją czysto metodologiczną, przestaje taką być, kiedy Amerykanin dodaje do niej w Scientific Man... frontalny atak na liberalizm jako ten prąd, który uniemożliwia zaistnienie światowego pokoju. Szczególnie interesujące jest, w jaki sposób Morgenthau definiuje liberalizm : terminem tym określa bowiem całość modernizujących i opartych na scjentyzmie działań, jakie w świecie Zachodu miały miejsce po rewolucji francuskiej. Wszystkie one bowiem, zdaniem Morgenthau, opierały się na wywodzonym przezeń z filozofii Milla przekonaniu, iż problemy społeczne są podobne są do problemów matematycznych i dają się racjonalnie rozwiązać. To jego zdaniem wynika z samej natury oświecenia jako epoki ślepej na ludzkie impulsy i irracjonalizm.

I chociaż pierwsza anglojęzyczna praca Hansa Morgenthau jest zakorzeniona w dziełach takich amerykańskich badaczy, jak Richard McKeon (inny filozof z Uniwersytetu w Chicago, z którym Morgenthau zetknął się podczas pobytu w stanie Illinois) - czytelnikowi Carla Schmitta łatwo będzie i w niej, i całym powojennym piśmiennictwie autora Polityki między narodami odnaleźć wątki wprost zaczerpnięte $\mathrm{z}$ dzieł filozofa $\mathrm{z}$ Plettenbergu powstałych w latach 20. i $30 .{ }^{49}$ Michael Williams uważał, iż „myśl Morgenthau w jasny sposób nosi znamię jego

${ }^{46}$ H. Morgenthau, Polityka między narodami. Walka o potęgę i pokój, przeł. R. Włoch, Warszawa 2010 , s. $20-30$.

${ }^{47}$ R. Osgood, The Mission of Morgenthau, [w:] K. Thompson, R.J. Myers (red.), Truth and Tragedy: A Tribute to Hans J. Morgenthau, New York 1984, s. 32.

${ }_{48}$ T. Tsou, ,, Scientific Man vs. Power Politics” Revisited, [w:] Truth and Tragedy, s. 43.

49 Podobieństwo do McKeona dostrzegł już jeden z pierwszych anglojęzycznych recenzentów, Read Bain. Zob.: R. Bain, Review of , Scientific Man vs. Power Politics” by Hans J. Morgenthau, „Social Forces” 1947, Vol. 25, s. 473. 
fascynacji Schmittem" "50, Hans Karl Pichler, explicite stwierdził zaś, iż Morgenthau nie należy do tradycji amerykańskiej filozofii politycznej i nazywał go tym filozofem, który przenosi do tej tradycji problemy stricte europejskie - i to w konceptualizacji, której poddał je Schmitt ${ }^{51}$. Trudno o lepszy sposób, by idee filozofa z Plettenbergu przedostały się do amerykańskiego dyskursu politycznego.

$\mathrm{Z}$ autorem Dyktatury Morgenthau pierwszy raz inaczej niż w sali wykładowej (był Schmitta studentem w Berlinie ${ }^{52}$ ) zetknął się pod koniec lat 20. XX wieku. W formie książkowej ukazała się wówczas jego doktorska dysertacja - Die internationale Rechtspflege, ihr Wesen und ihre Grenzen - którą, jak stwierdził pod koniec życia, napisał jako odpowiedź na wydane w 1927 r. Pojęcie polityczności Schmitta. O tyle nie można wierzyć temu twierdzeniu Morgenthau że, jak zauważa Oliver Jütersonke, nazwisko filozofa z Plettenbergu ani razu we wzmiankowanej książce nie pada ${ }^{53}$. Także jej topika nie była w momencie pisania schmittiańską: praca Morgenthau dotyczy bowiem prawa międzynarodowego, którym Schmitt miał się zająć dopiero pod koniec następnego dzięsięciolecia.

Morgenthau w swojej dysertacji rozważał problem, do jakiego stopnia państwa są zobligowane do rozwiązywania sporów między sobą na poziomie międzynarodowym, przed specjalnie do tego celu utworzonymi ciałami, które są w swoich materialnych decyzjach nieograniczone i mogą przedstawiać decyzje polityczne jako prawne. Nie chodziło mu jednak o podejmowanie prostej opozycji prawne - polityczne: stwierdził nawet, że taka nie istnieje, a antytezą politycznego jest niepolityczne, nie zaś prawne ${ }^{54}$. Tym, co odróżnia polityczne od niepolitycznego Morgenthau uczynił intensywność. I chociaż w istocie problem tej drugiej antynomii jest schmittiański, to analizowanie jej na przykładzie decyzji międzynarodowych organów - już nie; Carl Schmitt w tamtym czasie wyrażał się o nich lekceważąco i z potępieniem (zwłaszcza o Lidze Narodów) ${ }^{55}$.

Gdy praca podówczas młodego badacza została opublikowana, zwróciła uwagę Schmitta, który umówił się z Morgenthau na spotkanie. To ostatnie, według autora Polityki między narodami, poszło źle, gdyż Schmitt wydał mu się „,naj-

${ }^{50}$ M. Williams, The Realist Tradition and the Limits of International Relations, Cambridge 2005, s. 7.

${ }^{51}$ H.K. Pichler, The Godfathers of Truth: Max Weber and Carl Schmitt in Morgenthau's „, Theory of Power Politics”, „Review of International Studies” 1998, 24, no. 2, s. 185 i n.

${ }^{52}$ Co interesujące, innym nauczycielem Morgenthau, z którym również polemizował, był wspomniany wyżej Franz Neumann, który odpowiadał za czarną legendę Schmitta w USA. Zob.: W. Scheuerman, Between the norm and the exception: The Frankfurt School and the rule of law, Cambridge 1994, s. 52.

${ }^{53}$ O. Jütersonke, Morgenthau, Law and Realism, Cambridge 2010, s. 52.

${ }^{54}$ Ibidem, s. 51-57.

${ }^{55}$ Zob. np.: C. Schmitt, Rzymski katolicyzm i polityczna forma, [w:] C. Schmitt, Teologia polityczna..., s. 125. 
gorszym człowiekiem, jakiego kiedykolwiek spotkał" ${ }^{56}$. Niezależnie od osobistej niechęci, która pojawiła się wówczas między tymi dwoma myślicielami, po wzmiankowanym spotkaniu Morgenthau podjął faktyczny (a nie tylko deklarowany po latach) z filozofem z Plettenbergu dialog, którego owocem było jego własne Pojęcie polityczności (opublikowane najpierw po francusku w 1933 r., a po angielsku dopiero po latach, bo w roku 2012). Morgenthau rozwinął w nim tezę o opozycji legalnego i politycznego, ujętą w Die internationale Rechtspflege..., koncentrując się na zdefiniowaniu tego, czym jest polityczność. To ostatnie przeprowadzał w kontrze do Schmitta (z którym zgadzał się w powtórzonym później w omawianych wyżej sześciu zasadach twierdzeniu, iż polityczność pozostaje odrębną od pozostałych sfer życia), uznając, że autor Rzymskiego katolicyzmu i politycznej formy mylił się, twierdząc, że główną cechą polityczności jest stosowanie rozróżnienia na przyjaciela i wroga. Według Morgenthau sprowadzenie polityczności do tego rozróżnienia jest zbytnim uproszczeniem. „Czy możemy uznać - pytał - że przyjaciel uobecnia to, co politycznie ma wartość, wróg zaś to, co jest jej pozbawione? Oczywiście nie". Ta krytyka nie oznacza jednak, że Morgenthau całkowicie odrzucał Schmitta koncepcję polityczności, stworzoną sześć lat przed wydaniem jego pracy. ,Ten, kto rozróżnia przyjaciela i wroga w realizacji swoich politycznych, moralnych, estetycznych czy ekonomicznych celów - pisał - odróżnia także to, co do realizacji tych celów doprowadzi, od tego, co w tym przeszkodzi" ${ }^{57}$. Według Morgenthau, w tym drugim rozróżnieniu zawiera się pierwsze; drugie rozróżnienie ponadto, pozwala oddzielić to, co polityczne, od tego, co politycznym nie jest.

Zdaniem Morgenthau, spotkanie pod koniec lat 20. zainspirowało także samego Schmitta - który obdarzył go „szczególnego rodzaju komplementem. Zmienił drugie (z 1932 r.) wydanie swojego Pojęcia polityczności wedle propozycji zawartych w mojej rozprawie doktorskiej, oczywiście ani razu mnie nie wymieniając" $" 58$. Koncepcją, którą Schmitt miał wykorzystać, była, wedle Morgenthau, wspomniana wyżej intensywność. Podobnie bowiem jak Morgenthau w pracy z 1929 r., Schmitt, by udowodnić swoją tezę, w 1932 r. odniósł się do obecnego wśród myślicieli politycznych z nurtu realizmu antropologicznego przekonania o złej naturze człowieka. Zdaniem Williama E. Scheurmana pracę Morgenthau z 1929 r. od dzieła Schmitta różniło to, że pierwszy szybko antropologię porzucił i w efekcie „zaoferował czytelnikowi legalno-socjologiczną konceptualizację intensywności politycznego konfliktu"s9. Scheuerman przychyla się do tezy, iż faktycznie wy-

\footnotetext{
56 H. Morgenthau, The Concept of the Political, New York 2012, s. 176.

57 H. Morgenthau, The Concept of the Political, s. 114.

58 H. Morgenthau, An Intellectual Autobiography, „Society” 1978, 15, no. 2, s. 67.

59 W.E. Scheuerman, Carl Schmitt: The End of Law, Lanham 1999, s. 233.
} 
danie Pojęcia polityczności z 1932 r. zostało w pewnym stopniu ukształtowane przez Morgenthau, zwracając jednocześnie uwagę, że dług, jaki obydwaj myśliciele mają u siebie, nie jest proporcjonalny. O ile bowiem Schmitt wykorzystał Morgenthau na początku lat 30., o tyle cała powojenna myśl Hansa Morgenthau jest zakorzeniona $w$ teorii polityki filozofa z Plettenbergu, a Morgenthau właściwie „nigdy nie był w stanie myśleć w sposób kreatywny o porządku światowym, ponieważ jego intelektualny bagaż zawierał zbyt wiele ze Schmitta"60.

Morgenthau, gdy zaczął pisać po angielsku, co prawda próbował dyskredytować autora Pojęcia polityczności (czasem w sposób zrozumiały dla niewielu - jak wówczas, gdy w 1948 r. nazywał go politycznym romantykiem z ducha Adama Müllera, odnosząc się w ten sposób do pracy Schmitta z 1919 r., w której to filozof z Plettenbergu polityczny romantyzm zapalczywie krytykował ${ }^{61}$ ), jednak jego geopolityczne dzieła z lat 40. i 50. wskazują jeśli nie na silną inspirację filozofem z Plettenbergu, to na podobny sposób myślenia o systemie międzynarodowym. Zestawiwszy Schmittiański Der Nomos der Erde im Völkerrecht des Jus Publicum Europaeum (pisany od połowy lat 30., wydany w formie książkowej w 1950 r.) z pracą Morgenthau The Twilight of International Morality z 1948 r., Chris Brown wyszczególnił kilka punktów, w których obydwaj myśliciele mówią jednym głosem. Podobnie jak Schmitt, Morgenthau był wielkim (i pełnym nostalgii) orędownikiem systemu międzynarodowego uformowanego przez pokój westfalski, opierającego się na równowadze sił suwerennych państw narodowych. Podobnie jak Schmitt, Morgenthau uważał, że tym, co system ów doprowadziło do upadku była doktryna Monroe z 1823 roku. I Morgenthau, i Schmitt uznawali powrót średniowiecznej instytucji wojny sprawiedliwej w imię liberalnej demokracji za wynaturzenie tej pierwszej instytucji. I Schmitt, i Morgenthau uważali, że czas państw narodowych minął - o ile ten pierwszy proponował zastąpienie ich większymi obszarami, o tyle ten drugi w swojej Polityce między narodami zaproponował stworzenie państwa światowego ${ }^{62}$ (Morgenthau nie był pierwszym, który w USA wysunął taką propozycję; po I Wojnie Światowej na polu politycznym podobna była dziełem prezydenta Thomasa W. Wilsona, który postrzegał światową federację, o której pisał już od 1887 r., jako naturalną konsekwencję istnienia Ligi Narodów $\left.{ }^{63}\right)$.

${ }^{60}$ W.E. Scheuerman, Carl Schmitt and Hans Morgenthau: Realism and Beyond, [w:] Truth and Tragedy, s. 53.

${ }^{61}$ H. Morgenthau, The Political Science of E. H. Carr, „World Politics” 1948, Vol. 1, No. 1, s. 134.

${ }^{62}$ C. Brown, The Twilight of International Morality? Hans J. Morgenthau and Carl Schmitt on the End of the Jus Publicum Europaeum, [w:] M.C. Williams (red.), Realism Reconsidered. The Legacy of Hans J. Morgenthau in International Relations, Oxford 2007, s. 42-61.

${ }_{63}$ Zob. np.: J.P. Baratta, The Politics od World Federation: United Nations, UN Reform, Atomic Control, New York 2004, s. 42. 
Wiele tych podobieństw nie wyklucza oczywiście wielu różnic - wynikających z Morgenthauowskich presupozycji i jego niezrozumienia myśli Schmitta, spełniających model wędrującego pojęcia, o którym pisze Mieke Bal. Zdaniem Williama E. Scheuermana bowiem, jakkolwiek Schmitt i Morgenthau wychodzą z podobnych założeń, różnią się w podejściu do sytuacji permanentnej wrogości na arenie międzynarodowej. Choć obydwaj są realistami, Morgenthau ma, wedle Scheuermana, prowadzić swoją koncepcję według „realizmu pokoju”, podczas gdy Schmitt - „realizmu wojny” (uwaga amerykańskiego internacjonalisty współbrzmi zresztą ze spostrzeżeniem Jacquesa Derridy, według którego, chociaż Schmitt proponuje myślenie kategoriami przyjaciela i wroga, $\mathrm{w}$ istocie wrogość jest dlań kategorią o wiele ważniejszą $\left.{ }^{64}\right)$. O ile Morgenthau wyraża przekonanie, że, bez względu na wszelkie niebezpieczeństwa tkwiące w ludzkiej naturze, zaprowadzenie pokoju jest możliwe, Schmitt koncentruje się się na „niekonsekwencjach i sprzecznościach współczesnego mu prawa międzynarodowego" ${ }^{65}$. O ile wreszcie Schmitt uznaje polityczność za sferę rządzącą się kategoriami całkowicie innymi niż moralność, o tyle Morgenthau sądzi, że polityka nie może się całkiem obejść bez moralnych zasad (która to teza, wyrażona po raz pierwszy przez amerykańskiego myśliciela w opisywanych wyżej sześciu zasadach realizmu, później zyskała argumentację psychologiczną i PR-ową, w ramach których pragnący zdobyć wyborcę polityk nie może posługiwać się wyłącznie argumentami siły, gdyż nimi wyborcy skusić się nie da ${ }^{66}$.

Cytowany Scheuerman, który swój punkt widzenia na Schmitta i Morgenthaua diametralnie zmienił, we wcześniejszej swojej publikacji, w której był Morgenthau'owi życzliwy, twierdził, iż to on, nie zaś Schmitt zasługuje na miano Hobbesa XX w. Nie wchodząc w ten spór, należy stwierdzić, iż autor Polityki między narodami był od Schmitta bardziej wpływowy, a jego poglądy na problem siły w stosunkach międzynarodowych, jak pisze Marcin Król, ,zdominowały nie tylko filozofię polityczną, ale i politykę amerykańską, gdyż niemal wszyscy jej teoretycy i praktycy (z Henry'm Kissingerem na czele) byli jego uczniami"'67. By koronnym jurystą (i, pod pewnymi względami, internacjonalistą) prezydenta USA został Schmitt, trzeba było, by uczniowie uczniów Morgenthau odkryli jego berlińskiego nauczyciela.

\footnotetext{
${ }^{64}$ J. Derrida, Politics of Friendship, przeł. G. Collins, London 1997, s. 138.

${ }^{65}$ W.E. Scheuerman, Carl Schmitt: The End of Law, s. 247.

${ }^{66}$ M. Król, Wielcy władcy, Warszawa 2014, s. 156.

${ }^{67}$ Ibidem, s. 157.
} 


\section{TRANSLACJA TEOLOGII NA FILOZOFIE}

O ile historia recepcji myśli Schmitta w USA za sprawą przeniesienia jej na kontynent amerykański przez Hansa Morgenthau mieści się w zbudowanym przez Mieke Bal modelu pojęć wędrujących między uczonymi (i za ich sprawą: także między środowiskami akademickimi), o tyle transpozycja idei Schmitta za sprawą Leo Straussa jest ciekawsza o tyle, że obrazuje wędrówkę pojęć między dziedzinami nauki, a więc wędrówkę interdyscyplinarną.Niderlandzka badaczka opisuje to pojęcie jako różne zarówno od transdyscyplinarności (która, według Bal, zakłada „niezmienną sztywność, wędrówkę bez zmiany”), jak i multidyscyplinarności (,poddanie obszarów wielu dyscyplin wspólnemu narzędziu analitycznemu”), dostrzegając, że ,żaden z tych wariantów nie ma sensu. Na każdym etapie potrzeba natomiast negocjacji, transformacji i ponownej oceny" ${ }^{\prime 68}$.

Podobnie jak Morgenthau, Leo Strauss - urodzony i wychowany w rodzinie ortodoksyjnych Żydów w Prusach w 1899 r., więc niemal równolatek Schmitta, wykształcony na uniwersytetach w Marburgu i Hamburgu ${ }^{69}$ - swoją amerykańską przystań znalazł w Illinois, na Uniwersytecie w Chicago, gdzie został „wpływowym profesorem, który rozprzestrzeniał myśl Schmitta po USA"70. Podczas gdy Morgenthau był wychowawcą raczej politycznych teoretyków, to Strauss - praktyków. Jak przypomina Shadia B. Drury, do jego uczniów zaliczali się m.in. Paul Wolfowitz, zastępca Sekretarza Obrony w pierwszej administracji George'a W. Busha, następnie zaś prezes Banku Światowego, ,jeden z głównych architektów wojny w Iraku (...), którego entuzjazm dla prowadzenia wojny jest w sposób oczywisty straussowski" "71 , jak również Abram Schulsky, dyrektor działającego między 2002 r. a 2003 r. Office of Special Plans (stworzonego przez Donalda Rumsfelda na potrzeby działań militarnych USA w Iraku i Afganistanie). Schulsky „publicznie deklarował, iż to Strauss ukształtował jego podejście do polityki (...), twierdził, iż to od Straussa nauczył się, że postępowanie wbrew normie jest życiem politycznym" "ᄁ2. Uczniami ucznia Straussa, Harveya Mansfielda, byli też William Kristol i Carnes Lord, członkowie administracji wiceprezydenta Dana Quayle'a. Jak w 2004 r. podsumowywał Nicholas Xenos, „straussiści są

${ }_{68}^{6}$ M. Bal, Wędrujące pojęcia..., s. 65.

${ }^{69}$ Zob.: A. Bloom, Leo Strauss, September 20, 1899 - October 18, 1973, „Political Theory” 1973, 2, s. 374.

${ }^{70}$ W. Palaver, Carl Schmitt's „Apocalyptic” Resistance against Global Civil War, [w:] R. Hamerton-Kelly (red.), Politics \& Apocalypse, Michigan 2007, s. 69.

71 S.B. Drury, The Political Ideas of Leo Strauss, New York 2005, s. x. Zob. także: J. Atlas, The Nation: Leo-Cons; A Classicist's Legacy: New Empire Builders, „The New York Times” z 04.05.2003, https://www.nytimes.com/2003/05/04/weekinreview/the-nation-leo-cons-a-classicist-s-legacy-new-empire-builders.html [dostęp: 24.07.2018].

72 S.B. Drury, The Political Ideas of Leo Straus, New York 2005, s. xi. 
w Waszyngtonie od dwóch dekad. Stworzony został obraz uczniów Straussa jako konspiracyjnej siatki lub wyznaniowej sekty, która posługuje się pewnym rodzajem zakodowanego języka"’3. W owym języku, za którego najważniejszy element Xenos uznaje traktowanie polityki Stanów Zjednoczonych w kategoriach moralnych (w popularnej wyobraźni obecnego za sprawą określenia „Imperium Zła”, które prezydent Reagan odniósł do Związku Radzieckiego) wyraźnie obecne są idee autora Pojęcia polityczności, w interesujący jednak przez Straussa sposób przeformułowane, gdyż poddane wskazywanej przez Mieke Bal transformacji, negocjacji i ponownej ocenie.

By zrozumieć, w jaki sposób i do tego przeformułowania, i do umieszczenia ich w amerykańskim dyskursie i praktyce politycznej doszło, trzeba się cofnąć do początków intelektualnej i osobistej relacji filozofa z Plettenbergu z autorem Prawa naturalnego w świetle historii. Ta rozpoczęla się w listopadzie roku 1931, gdy Strauss odwiedził Schmitta w jego mieszkaniu w Berlinie. „Doktor Strauss zapowiedział się na piątą, przyszedł, wytworny Żyd, uczony, pracuje nad Hobbesem, podobała mi się jego praca" - zapisał w dzienniku Schmitt pod datą 27 listopada $^{74} .21$ grudnia Strauss przyniósł Schmittowi manuskrypt swojej recenzji jego Pojęcia polityczności, a Schmitt zaaranżował jej publikację w periodyku, który wydrukował wcześniej Pojęcie... Na początku roku 1932 Strauss poprosił Schmitta o napisanie rekomendacji, która umożliwiłaby mu otrzymanie stypendium Fundacji Rockefellera. Gdy je otrzymał, opuścił Berlin i udał się do Pary$\dot{z ̇ a}^{75}$. Schmitt zerwał kontakty ze Straussem w 1933 r., zaraz po dojściu nazistów do władzy. Było to z jego strony działanie oportunistyczne, bo do intelektualnego namysłu nad Straussem wrócił zaraz po wojnie (a i przed nią, jak uważa Reinhard Mehring, silnie się Straussem inspirował przy pisaniu w 1938 r. swojej pracy na temat Lewiatana Tomasza Hobbesa) $)^{76}$. O sile więzi między Schmittem a Straussem, dodaje Heinrich Meier (twórca tezy, iż między oboma filozofami istniał „ukryty dialog”), świadczy też, iż autor Pojęcia polityczności był jednym z trzech - obok Martina Heideggera i Alexandre’a Kojève’a - współczesnym Straussowi filozofem, któremu poświęcał on swe rozważania ${ }^{77}$.

Według Stephena Holmesa tym, co łączyło Straussa i Schmitta była niechęć do liberalizmu; zetknąwszy się, porozmawiawszy i zaczerpnąwszy od siebie część idei, obaj wrócili do rozwijania własnych koncepcji ${ }^{78}$. Odmienność obranej drogi

${ }^{73}$ N. Xenos, Leo Strauss and the Rhetoric of the War on Terror, „Logos” 2004, 3.2, http://www. logosjournal.com/xenos.htm [dostęp: 10.01.2019].

${ }_{74}$ Cyt. za: R. Mehring, Carl Schmitt. A Biography, przeł. D. Steuer, New York 2014, s. 248.

75 R. Mehring, Carl Schmitt. A Biography, s. 248-250.

${ }^{76}$ Ibidem, s. 251.

${ }^{77}$ H. Meier, Carl Schmitt and Leo Strauss: The Hidden Dialogue, Chicago 1995, s. 11.

${ }^{78}$ S. Holmes, The Anatomy of Anti-Liberalism, Chicago 1993, s. 60. 
badawczej pokazuje wspomniana recenzja Straussa z Pojęcia polityczności. Krytyczne zdanie Straussa na temat eseju Schmitta brało się z faktu, iż dezaprobatę w stosunku do liberalizmu zaprezentowaną przez filozofa z Plettenbergu odbierał Strauss jako nie dość ostrą ${ }^{79}$. Straussowi Schmitt ,ze swoją niedostatecznie jasno dookreśloną teorią polityczności wydawał się pozostawać w horyzoncie liberalizmu, dla którego polityka jest tylko jednym z wielu obszarów kultury ludzkiej"80. $\mathrm{Z}$ tego też względu, twierdził Strauss, pisząc o polityczności, Schmitt w istocie afirmował hobbesowski stan natury, pozostający sytuacją permanentnego zagrożenia wojną i nie dostrzegał, iż antynomia przyjaciela i wroga jest przeciwieństwem metafizycznym, nie zaś elementem gry politycznej. Schmitta krytyka liberalizmu pozostawała dla Straussa pusta i nie ,wyszczególniała, co ma stanowić o prawomocności panującej ideologii czy osoby" ${ }^{\text {"1 }}$. Autor Pojęcia polityczności, według Straussa, okazywał się równie neutralny jak liberałowie, których pragnął zwalczyć: jego koncepcja polityczności była pozbawiona moralnej przestrzeni, którą można wypełnić jakąkolwiek polityczną ideą.

Heinrich Meier twierdzi, że tego rodzaju opinia Straussa o Schmitcie wzięła się z faktu, iż o ile argumenty filozofa z Plettenbergu z Pojęcia polityczności oparte były na teologii politycznej (która boskie objawienie ma „za najwyższy autorytet i ostateczny fundament stwarzający podział na przyjaciół i wrogów"\$2), o tyle argumenty Straussa czerpały swą siłę z politycznej filozofii, którą po latach, w eseju What Is Political Philosophy? z 1959 r., przedstawiał jako wywodzącą się z refleksji moralnej, dotyczącej społeczeństwa i jego wewnętrznego ładu ${ }^{83}$. „Dla Schmitta - jak twierdzi Meier - afirmacja polityczności była niczym innym, jak afirmacją moralności, którą widział jako opartą na teologii: afirmacja moralności była zatem częścią teologii politycznej" ${ }^{84}$, dla Straussa natomiast, odrzuca-

${ }^{79}$ Zob.: R. Cristi, Carl Schmitt and Authoritarian Liberalism: Strong State, Free Economy, Cardiff 1998, s. 172.

${ }^{80}$ Ł. Święcicki, Carl Schmitt i Leo Strauss. Krytyka pozytywizmu prawniczego w niemieckiej myśli politycznej, Warszawa 2015, s. 107.

81 J.P. McCormick, Teaching in vain, [w:] The Oxford Handbook of Carl Schmitt, s. 271.

${ }^{82}$ H. Meier, Czym jest teologia polityczna? Wstępne uwagi na temat kontrowersyjnego pojęcia, przeł. M. Kurkowska, „Teologia Polityczna” 2003/2004, 1, s. 182.

${ }^{83}$ Zob.: A. Wielomski, Koncepcje schyłku myśli politycznej we współczesnej politologii, „Doctrina" 2006/2007, s. 163.

${ }^{84}$ H. Meier, Carl Schmitt and Leo Strauss: The Hidden Dialogue, s. 249. Warto w tym miejscu zaznaczyć, iż podobnie jak tez zawartych w pracy doktorskiej Morgenthau, Schmitt nie potraktował uwag autora Prawa naturalnego w świetle historii lekceważąco: kolejne wydania jego Pojęcia polityczności zawierają liczne zmiany wynikacące z uważnej lektury recenzji autorstwa Straussa. Jedna tych zmian, której Meier uznaje za szczególnie znaczącą, dotyczy myślenia o instytucji wojny, która w pierwszym wydaniu Pojęcia polityczności nie była dla Schmitta „,zymś pobożnym, etycznie dobrym czy korzystnym". Owo zastrzeżenie w drugim wydaniu eseju filozof z Plettenbergu obwarował słowem „dziś”. W wydaniu trzecim, poprawionym po recenzji Straussa, Schmitt postanowił 
jącego teologię jako fundament myślenia o polityczności, legitymizacja panującej ideologii czy osoby pozostawała kwestią do dalszego rozważenia, a porzucenie sądów o wartościach w filozofii politycznej stanowiło główną cechę współczesnej mu myśli liberalnej. To przyjęcie odmiennych perspektyw widoczne jest właściwie we wszystkich obszarach myśli Straussa i Schmitta, które opieraja się na podobnych założeniach. Przykładowo, obydwu myślicieli łączyło wywiedzione z Hobbesa przekonanie o złej naturze człowieka; jednak podczas gdy Strauss twierdził, iż natura ta musi być wciąż doskonalona, Schmitt uważał, że w niej samej tkwi niebezpieczeństwo osuwania się w neutralność (traktowaną jako z poddawanie się zgubnemu wpływowi technologii). Toteż utrzymanie się umowy społecznej uzależniał Strauss od ciągłej edukacji ludzi, którzy są tą umową związani. Schmitt z kolei wierzył w polityczną antynomię przyjaciel - wróg jako fundamentalną dla utrzymania strachu i, co za tym idzie, trwałej jedności politycznej. To w strachu wszak zawarte było poczucie polityczności i, co za tym idzie, moralna, bo teologiczna, legitymizacja działań suwerena ${ }^{85}$.

Najgłębiej jednak antynomia politycznej filozofii i politycznej teologii unaocznia się w tym punkcie myśli Leo Straussa, zainteresowanie którym autor Prawa naturalnego w świetle historii od autora Pojęcia polityczności przejął: sytuacji wyjątkowej. Zdaniem Roberta Howse'a, to właśnie wpływ, jaki Schmitt wywarł na Straussa, zaowocował włączeniem do jego interpretacji prawa naturalnego problemu wyjątku i zawieszenia normy. Autor Prześladowania i sztuki pisania potraktował go jako ,zadanie znalezienia przestrzeni pomiędzy będącej przedmiotem klasycznego prawa naturalnego celebracji ludzkiej doskonałości i potrzebą bezpieczeństwa publicznego" "86. Przeciętny czytelnik mógłby uznać, że gdy w wydanym w 1953 r. Prawie naturalnym $w$ świetle historii Strauss pisze, iż

w skrajnych sytuacjach mogą zachodzić konflikty między tym, czego wymaga zachowanie społeczności, a tym, czego wymaga »zamienna« i »rozdzielcza« sprawiedliwość. W takich sytuacjach, i tylko w takich, można słusznie powiedzieć, że bezpieczeństwo publiczne jest najwyższym prawem ${ }^{87}$,

\footnotetext{
Pojęcie... wzbogacić o dookreślenie owego „dziś”, pisząc wprost o „epoce, która maskuje ekonomią swe metafizyczne przeciwieństwa". Zob.: C. Schmitt, Pojęcie polityczności, [w:] C. Schmitt, Teologia polityczna..., s. 265 .

${ }^{85}$ Zob.: J.P. McCormick, Fear, Technology, and the State: Carl Schmitt, Leo Strauss, and the Revival of Hobbes in Weimar and the National Socialist Germany, „Political Theory” 1994, 22, No 4, s. 625-631.

${ }^{86}$ R. Howse, From Legitimacy to Dictatorship - and Back Again: Leo Strauss's Critique of the Anti-Liberalism of Carl Schmitt, „The Canadian Journal of Law and Jurisprudence” 1997, vol. 10, s. 91.

${ }^{87}$ L. Strauss, Prawo naturalne w świetle historii, przeł. T. Górski, Warszawa 1969, s. 149.
} 
powtarza tezy Schmitta z Teologii politycznej i komentarza do artykułu 48 konstytucji Republiki Weimarskiej. A jednak poprzez refleksę nad sytuacją wyjątkową Strauss dokonał interdyscyplinarnej - z teologii politycznej na filozofię - negocjacji, transformacji i ewaluacji myśli Schmitta, o jakiej pisała Mieke Bal. O ile bowiem dla zakładającego moralny, bo teologiczny, charakter działań ze sfery polityczności Schmitta legitymizacją postępowania suwerena podczas trwania stanu wyjątkowego był ich transgresyjny charakter - zawieszenia publicznego porządku i bezpieczeństwa celem ich obrony - o tyle nieuznający podobnych wartości Strauss musiał odszukać legitymizację inną.

Tę ostatnią odnalazł na gruncie prawa naturalnego, które w swoim odczytaniu Arystotelesa interpretował Strauss jako posiadające dwie cechy: po pierwsze, będące częścią prawa politycznego, po drugie - mające charakter zmienny. O ile, jak zaznacza André Luiz Cruz Sousa, ta pierwsza cecha nie budzi większego zdziwienia, o tyle ta druga jest już zaskakująca i bierze się z dostrzeżonego przez Straussa sporu wśród komentatorów Arystotelesowskiej idei. Niektórzy komentatorzy Arystotelesa bowiem (na przykład Awerroes), interpretowali jego wizję prawa naturalnego jako zestaw szerokich reguł sprawiedliwości obowiązujących wszędzie, niezależnie od tradycji czy systemu, dodając, że to obowiązywanie zasadza się na okazjonalnym jego zawieszaniu (gdy status quo jest zagrożone). Komentatorzy inni (św. Tomasz z Akwinu) - postrzegali Arystotelesowskie prawo naturalne jako dostrzegalny za sprawą synderezy zbiór niezmiennych zasad, z których dopiero wyprowadzane są te, które podlegają zmianie ${ }^{88}$. Strauss obydwie te interpretacje odrzucił, jedną mając za Scyllę absolutyzmu, drugą zaś - za Charybdę relatywizmu. Interpretacja awerroistyczna „zawiera zaprzeczenie właściwego prawa naturalnego" ${ }^{89}$, tomistyczna zaś wprowadza rozróżnienie, którego brakuje w oryginalnym tekście. By obydwu uniknąć, Strauss odniósł się do innego elementu myśli Arystotelesa - hierarchii celów, która jest dla myślenia o sytuacji ekstremalnej o tyle przydatną, iż zakłada, że ,istnieje powszechna ważność hierarchii celów, lecz nie ma powszechnie ważnych zasad działania"90.

Autor Prześladowania i sztuki pisania definiował sytuację ekstremalną jako taką, „w której zagrożone jest samo istnienie czy niezależność społeczeństwa”, jako przykład podając choćby wojnę $e^{91}$. W sytuacji takiego rodzaju wspólne dobro - którego istnienie jest równoważne ze skutecznością zasad wyrażonych w prawie - znajduje się w sytuacji zagrożenia: nie jest pewne ani jasne, czy uda mu się przetrwać. I o ile klasyczna hierarchia celów stawia publiczne bezpieczeństwo

${ }^{88}$ Zob.: A.L. Sousa, Thoughts on Leo Strauss's Interpretation of Aristotle's Natural Right Teaching, „The Review of Politics” 2016, 78, 3, s. 421 i nn.

${ }^{89}$ L. Strauss, Prawo naturalne w świetle historii, s. 148.

${ }^{90}$ L. Strauss, Prawo naturalne w świetle historii, s. 151.

${ }^{91}$ L. Strauss, Prawo naturalne w świetle historii, s. 149. 
poniżej sprawiedliwości, o tyle sytuacja ekstremalna ten porządek odwraca. Co istotne, idąc schmittiańskim tropem, Strauss zaznacza, iż „nie ma zasady, która określałaby wyraźnie, w jakim przypadku ważniejsze jest publiczne bezpieczeństwo, a w jakim ścisłe zasady sprawiedliwości" ${ }^{22}$, w którym to zdaniu czytelnik usłyszy echo porównania stanu wyjątkowego do cudu, którego nie można przewidzieć przed jego zaistnieniem. Jednak Schmitt uważa, że

nie da się w prostych, jasnych kategoriach określić warunków koniecznych do uznania danej sytuacji za wyjątkową. Nie da się również dokładnie wyliczyć, jakie działania są dopuszczalne w sytuacji naprawdę skrajnej, którą chcemy opanować. Warunki, jak i treść kompetencji są tu z konieczności nieograniczone ${ }^{93}$,

Strauss natomiast, stwierdziwszy, że „nie ma granic, które można by z góry określić, granic, w obrębie których nawet odwet można uznać za sprawiedliwy", dodaje, że „to, czego nie można z góry ustalić za pomocą ogólnych zasad (...) może w krytycznym momencie natychmiast ustalić najzdolniejszy i najbardziej dokładny mąż stanu" ${ }^{94}$. Schmittiańskiego suwerena, którego kompetencje są nieograniczone, zastępuje posiadający najlepsze kwalifikacje urzędnik, który wybiera działania jego zdaniem najwłaściwsze.

Strauss idzie zatem tropem Schmitta - ale nie tego, który w Teologii politycznej i Pojęciu polityczności był, jego zdaniem, myślicielem afirmującym polityczność jako stan ciągłego zagrożenia wojną, która zdawała mu się polityczności najgłębszym wyrazem. Podczas gdy w tym drugim tekście Schmitt podejmował polemikę z Carlem Clausewitzem i jego roszczeniem, by na działania militarne patrzeć z perspektywy racjonalnej i widzieć w wojnie, w której dokonało się „odrzucenie pojęcia agresji i odpowiedzi na agresję; zapomnienie działania opartego na wzajemności" ${ }^{95}$, to we wcześniejszej o kilka lat Dyktaturze był racjonalnej konceptualizacji zwolennikiem. W tekście tym, w którym, inaczej niż w Teologii politycznej, sytuacja wyjątkowa, jak uważa John McCormick, opisana została jako niepożądana, jawił się Schmitt jako zwolennik tego sposobu postrzegania tytułowej instytucji, jak w starożytnym Rzymie - wyznaczania na dyktatora komisarycznego (nie zaś suwerennego) obywatela o nieposzlakowanej opinii, by załatwił jedną, konkretną sprawę dowolnymi dostępnymi mu środkami ${ }^{96}$. O tyle jednakowoż myśl Schmitta Strauss rozwinął, że dla tego pierwszego i działania

${ }_{92}$ L. Strauss, Prawo naturalne $w$ świetle historii, s. 150.

${ }^{3}$ C. Schmitt, Teologia polityczna. Cztery rozdziały poświęcone pojęciu suwerenności, [w:] C. Schmitt, Teologia polityczna i inne pisma, s. 46.

94 L. Strauss, Prawo naturalne w świetle historii, s. 150.

95 R. Girard, Apokalipsa tu i teraz, przeł. C. Zalewski, Warszawa 2018, s. 56.

${ }^{96}$ Zob.: J. McCormick, Carl Schmitt's Critique of Liberalism: Against Politics as Technology, Cambridge 1999, s. 283. 
dyktatorskie, i działania suwerena w momencie trwania stanu wyjątkowego wypływają z normatywnej pustki „i na dobrą sprawę nie różni[ą] się (...) od zachowania żołnierza, który decyduje, czy ten, kto stoi naprzeciwko, to wróg, czy przyjaciel" ${ }^{\prime 97}$. Strauss, dokonując przeniesienia pojęcia z porządku teologii politycznej na porządek politycznej filozofii, wzbogacił go o element racjonalnego zarządzania państwem, czyli: element kompetencji, jaką polityk działający w stanie zagrożenia państwa musi posiadać. Uniknął w ten sposób i schmittiańskiej afirmacji polityczności jako ciągłego zagrożenia (zwracając się ku sytuacji normalnej jako wyrazowi poważania nawet $\mathrm{w}$ momencie wyjątkowym arystotelejskiej hierarchii celów) i zalegitymizował działania podejmowane w momencie stanu wyjątkowego komponentem moralnym, dla Schmitta wynikającym z teologicznej bazy.

W Departamencie Stanu podczas pierwszej kadencji prezydenta Reagana - uważa Nicholas Xenos - więcej pracowało urzędników biegłych w filozofii Straussa niż w kulturach narodów, z którymi USA współpracowały lub które zwalczały ${ }^{98}$. Częste porównywanie przez niektórych komentatorów i analityków administracji aktualnej do tej z lat 80 . sugeruje, iż Leo Strauss wciąż pozostaje w tym środowisku myślicielem wpływowym ${ }^{99}$. Wraz z nim - autor rekomendacji stypendialnej dla Fundacji Rockefellera, która umożliwiła twórcy Prawa naturalnego $w$ świetle historii wyjazd z Niemiec i, wreszcie, trafić do Stanów Zjednoczonych.

\section{CARL SCHMITT JAKO PHARMAKON}

Nie tylko amerykańska prawica zainteresowała się w drugiej połowie XX w. myślą Carla Schmitta; sięgnęli do niej także, wcześniej niż w Europie, myśliciele lewicowi. Oczywiście, jak już wspomniałem, ci ostatni interesowali się filozofem z Plettenbergu także w latach 60. i 70., było to jednak zainteresowanie ideologiczne, a nie namysł intelektualny. W USA lewicowcy czytali Schmitta selektywnie, w myśl stwierdzenia, że, jak tuż po wojnie pisał o filozofie z Plettenbergu Frederick E. Dessauer, „nauczanie heretyków jest przydatne, jeśli chodzi o znajdowanie słabych punktów we własnej myśli”’100. Wędrówka autora Po-

${ }_{97}$ P. Nowak, Młody Schmitt, [w:] C. Schmitt, Dyktatura. Od źródet nowożytnej idei suwerenności do proletariackiej walki klas, przeł. K. Wudarska, Warszawa 2016, s. Xv.

${ }_{98}$ N. Xenos, Leo Strauss and the Rhetoric of the War on Terror.

99 Zob. np.: R. Baker, The Echoes of Reagan in Trump's National Security Strategy, raport agencji wywiadowczej „Stratfor”, https://worldview.stratfor.com/article/echoes-reagan-trumps-national-security-strategy [dostęp: 22.11.2018].

${ }^{100}$ F.E. Dessauer, The Constitutional Decision: A German Theory of Constitutional Law and Politics, „Ethics” 1946, Vol. 57, No. 1, s. 14. 
jęcia polityczności z kręgu jednej politycznej proweniencji do drugiej czyniła z niego, by użyć określenia Jacquesa Derridy, pharmakon: zarówno truciznę własnej myśli, jak i odtrutkę na jej słabość, a przede wszystkim: ofiarę, którą można na ołtarzu owej własnej myśli złożyć i w ten sposób ją wzmocnićc ${ }^{101}$. Tymi, którzy ją w USA składali, byli autorzy związani z kwartalnikiem „Telos”, założonym w 1968 r. Początkowo teksty publikowane w „Telos” koncentrowały się wokół badań nad zachodnim marksizmem i filozofią Szkoły Frankfurckiej (rozważania nad którą, jak twierdzi krytyczny wobec tego trendu Roger Scruton, doprowadziły do rozkwitu myślenia lewicowego w USA ${ }^{102}$ ) i to właśnie związki Schmitta z myślicielami z nurtu Adorna prezentował pierwszy opublikowany w nim dotyczący filozofa z Plettenbergu artykuł (Carl Schmitt and the Frankfurt School autorstwa Ellen Kennedy z roku 1987).

Autorów i redaktorów „Telos” w drugiej połowie lat 80. nie interesował Schmitt sam w sobie, lecz jako punkt wyjścia do rozważania nad upadkiem lewicy i utratą przez nią politycznej mocy. Trudno się temu dziwić: w USA Ronald Reagan właśnie po raz kolejny wygrał wybory prezydenckie, w Europie Wschodniej zaś komunizm zaczynał się chwiać. Wszystko to stało się dlatego, że „lewica - według założyciela i długoletniego redaktora naczelnego „Telosu”, Paula Piccone - stała się komformistyczna i bezkrytyczna", a dominujący paradygmat uprawiania polityki - na wzór zarządzania korporacją - uniemożliwił jej zradykalizowanie się. Doprowadziło to do podporządkowania lewicy kapitalistycznej racjonalizacji, w ramach której bierze ona ,udział w budowaniu Welfare State i pozostaje nieobecna"103. Dlatego też, wedle Piccona, lewica winna znaleźć nową formułę i poddać krytyce działania prawicy, zamiast usprawiedliwiać swym postępowaniem działania liberałów.

Przez następne lata redaktorzy pisma spierali się o Schmitta, co przedstawił Piccone i inny związany z pismem filozof, G.L. Ulmen. Schmitt jest w tym tekście dla Piccona i Ulmena istotny jako wróg - w dwóch aspektach. Po pierwsze, ważna jest dla nich jego filozofia przyjaciela i wroga, po drugie, ważny jest sam Schmitt jako figura wroga, filozof wywodzący się z kręgów prawicowych i konserwatywnych. Jeśli chodzi o ten pierwszy punkt, lewica w latach 80., uważają Piccone i Ulmen, nie potrafiła określić swojego głównego przeciwnika, traktując każdą kolejną ideologię jako taką, z którą należy podjąć dialog. Piccone i Ulmen argumentowali, że choć lewica może nie uznawać odpowiedzi

101 Zob.: T. Corn, Clausewitz in Wonderland, „Policy Review” Web Special, September 2006, https://www.researchgate.net/publication/304578949_Clausewitz_in_Wonderland [dostęp: 23.04.2018].

102 R. Scruton, Fools, frauds and firebrands, s. 147.

${ }^{103}$ P. Piccone, Why did the Left Collapse?, „Telos” 1980-1981, 46, s. 92 i n. 
Schmitta na pytania dotyczące wrogości za słuszne, powinna zastanowić się nad tym, jak zostały one udzielone ${ }^{104}$. Trudno się dziwić, że przywołanie przez dwóch lewicowców filozofii autora Teologii politycznej spotkało się z oburzeniem ich ideologicznych pobratymców. Dwa numery później historyk idei Jeffrey Herf opublikował tekst wobec Piccona i Ulmena polemiczny, w którym przestrzegał przed odwoływaniem się do filozofii Carla Schmitta. Główne niebezpieczeństwo jego myśli polegało zdaniem Herfa na tym, iż sposobu na rozwiązanie wewnętrznych problemów republiki weimarskiej upatrywał Schmitt w rządach autorytarnych. W swoim eseju Herf poruszył również problem zaangażowania autora Pojęcia polityczności w ruch nazistowski. Jeśli już lewicowcy chcą korzystać z dorobku konserwatystów - argumentował - to dlaczego ze Schmitta właśnie, nie zaś z Churchilla, Alexandra Hamiltona? ${ }^{105}$ Redaktorzy „Telos” odpowiedzieli Herfowi w tym samym numerze, stwierdzając, iż Schmitt dołączył do nazistów nie z racji podobnych upodobań politycznych, ale z racji oportunizmu; czytać go, twierdzili, to pokazywać, że ma się otwarty umysł, bowiem Schmittiańska krytyka liberalizmu, technologii i uniwersalizmu może być przydatna lewicy ${ }^{106}$.

Ta ostra wymiana zdań spowodowała, że autorzy „Telosu” przez pewien czas nie poruszali tematu Carla Schmitta. Temat ten na łamach kwartalnika pojawił się znowu już w następnej dekadzie i powracał regularnie przy różnych okazjach: kryzysu liberalizmu (widzianego w Europie po upadku Żelaznej Kurtyny), populizmu (wzrostu popularności Ligi Północnej we Włoszech), federalizmu i jedności państwa oraz jego wewnętrznej neutralizacji, przemian wewnątrz Kościoła katolickiego i wreszcie jako samodzielna kwestia. Najszerzej o Schmitcie pisano w 1996 r., kiedy to „Telos” opublikował cały numer jemu poświęcony, pt. Carl Schmitt Now. Jest to zbiór tekstów o tyle istotny, że nacisk w nim został położny na tę część myśli Schmitta, którą jego badacze i uczniowie zwykli dotychczas pomijać milczeniem: jego powojennych teorii geopolitycznych. Jeszcze w $2002 \mathrm{r}$. fińska badaczka Mika Luoma-Aho, utyskując na stan anglojęzycznych badań nad dorobkiem myśliciela z Plettenbergu stwierdziła, iż „mnogość opracowań dzieł Schmitta dotyczących filozofii prawa i polityki powstałych w okresie Republiki Weimarskiej kontrastuje z brakiem studiów na temat jego późniejszych prac dotyczących geopolityki" ${ }^{107}$. O taki stan rzeczy łatwo można obwinić opisanych wyżej, konserwatywnych importerów myśli autora Pojęcia polityczności do USA

104 P. Piccone, G.L. Ulmen, Introduction to Carl Schmitt, „Telos” 1987, 72, s. 3 i n.

105 J. Herf, P. Piccone, G.L. Ulmen, Reading and Misreading Schmitt, „Telos” 1987, 74, s. 133.

106 Ibidem, s. 150.

107 M. Luoma-Aho, Carl Schmitt and the Transformation of the Political Subject, „The European Legacy" 2000, s. 703. 
- zarówno Morgenthau, jak i Strauss znali wszak Schmitta osobiście z lat 20. i 30. i dlatego to głównie idee z tamtego czasu włączyli do amerykańskiego dyskursu, nie zauważając Schmittowego nawrócenia z decyzjonizmu na instytucjonalizm. Nawet geopolityczna teoria Morgenthau jest silnie zakorzeniona w pracach Schmitta z lat 20. i 30., a jedyna wycieczka w stronę jego powojennej myśli to pochwała jus publicum europaeum.

Powojenny, geopolityczny Schmitt swoich czytelników w Ameryce znalazł zatem wśród redaktorów „Telos”. Analizując na łamach tego pisma Schmittiański Nomos ziemi, G.L. Ulmen - późniejszy thumacz tej pracy na angielski - skonfrontował tezy Schmitta na temat prawa wywodzącego się zaboru terytorium z pracami współczesnych mu politologów (Fukuyamy i Huntingtona) by stwierdzić, iż pominięcie przez tych ostatnich kluczowego dla Schmitta czynnika geograficznego w ich teoriach konfliktu uczyniło teorie owe niepełnymi ${ }^{108}$. W tym samym numerze „Telos” Ulmen opublikował kolejny tekst na temat internacjonalistycznej myśli Schmitta, w którym za myślicielem z Plettenbergu argumentował, że cały XX w. był czasem braku ograniczeń dla wojny (które to ograniczenia pojawiły się po zawarciu pokoju westfalskiego), z czego wynikła hekatomba lat 40.; wnosił o stworzenie nowego nomos ziemi ${ }^{109}$. W tym samym numerze Joseph E. Bendersky jako przykład tekstu Schmitta zrozumiałego dopiero pod koniec XX w. podawał jego pracę o Hobbesie.

Ten sam Bendersky osiem lat później, w zimowym numerze „Telos” z 2002 r. opublikował esej na interesujący nas temat: wpływu autora Teologii politycznej na politykę międzynarodową USA. Rozprawiwszy się z nazistowskimi konotacjami Schmitta, Bendersky uznał go za myśliciela, którego głównym ideałem w dziedzinie polityki było osiągnięcie stabilności przez dany polityczny organizm. Według Bendersky’ego, Schmitt miał wpływ na kluczowych myślicieli politycznych USA dwudziestego wieku: Hayeka i Schumpetera, a cały amerykański konserwatyzm przepojony jest jego duchem $-\mathrm{z}$ weimarskiego okresu jego twórczości ${ }^{110}$. Być może to właśnie skupienie na tym etapie zaowocowało tak niezgodnym z poglądami samego autora Pojęcia polityczności tekstem, jak ten pochodzący z tego samego numeru „Telosu” esej Luisa Maríi Bandieriego, argumentującego, że po atakach z 11 września 2001 r. niezbędny jest działający zgodnie z ideą Schmitta globalny suweren ${ }^{111}$. Kilka numerów „Telosu” później G.L. Ulmen określił wojnę z terrorem mianem globalnej wojny domowej, przypominającej walkę frakcyjną w republice

108 G.L. Ulmen, Toward a New World Order; Introduction to Carl Schmitt's The Land Appropriation of a New World, „Telos” 1996, 109, s. 42.

109 G.L. Ulmen, Just Friends or Just Enemies, „Telos” 1996, 109, s. 182.

110 J.E. Bendersky, The Definite and the Dubious: Carl Schmitt's Influence on Conservative Political and Legal Theory in the U.S, „Telos” 2002, 122, s. 33-47.

${ }^{111}$ L.M. Bandieri, Carl Schmitt and Federalism, „Telos” 2002, 122, s. 48-58. 
weimarskiej za czasów Schmitta ${ }^{112}$. Jego teza nie budziła już wtedy kontrowersji: podobne formułowano na łamach popularnej prasy. I dzięki „Telosowi”, i starszym o pokolenie myślicielom konserwatywnym, Carl Schmitt zadomowił się w amerykańskim dyskursie politycznym. Wędrówka się skończyła, idee dotarły do celu.

\section{PODSUMOWANIE}

Swoją popularność w dotyczącym zjawisk politycznych dyskursie we współczesnych Stanach Zjednoczonych Carl Schmitt zawdzięcza specyficznej wędrówce trzech pojęć (w rozumieniu zaproponowanym przez Mieke Bal), składających się na jego myśl polityczną: polityczności, stanu wyjątkowego i decyzjonizmu. Ich wędrówka z Europy do USA możliwa była dzięki trzem szczególnym przewoźnikom: Hansowi Morgenthau, który zaadaptował Schmittiańskie myślenie o polityczności do warunków geopolityki prowadzonej przez USA w drugiej połowie XX wieku, Leo Straussowi, który dokonał transferu Schmittiańskiej koncepcji stanu wyjątkowego z politycznej teologii do filozofii, oraz lewicowym myślicielom skupionym wokół pisma „Telos”, którzy użyli jej do stworzenia ideowej podbudowy dla odrodzenia lewicy w USA. Różna była ranga tych myślicieli i ich stosunek do Schmitta, każdy jednak przyczynił się do wejścia autora Pojęcia polityczności w amerykański dyskurs polityczny. Na ile zaowocowało to nie tylko powstaniem użytecznego narzędzia analizy amerykańskiej polityki, a także stało się ideową podbudową prowadzonych w jej ramach działań, pozostaje tematem na osobny artyku1.

\section{RECEPTION OF CARL SCHMITT'S THOUGHT IN THE USA AFTER 1945}

\section{Summary}

Numerous scholars indicate Carl Schmitt's influence on the modern US politics. It is a certain type of a paradox because Carl Schmitt himself considered the United States to be a state with a political system which is not well prepared for the acceptance of the decisionist political philosophy. First texts concerning this philosophy which were written in the United States also were not very kind towards it. The paper discusses - with the use of the theory of wandering concepts created by the Dutch researcher Mieke Bal - how Carl Schmitt's ideas travelled from Germany to the USA. The article indicates that they were transferred to the American soil by Hans Morgenthau (who applied Schmitt's theory to international relations), Leo Strauss (who translated his political theology into political philosophy) and left-wing thinkers gathered around the "Telos" journal who interpreted Schmitt's thoughts differently than Schmitt did.

${ }^{112}$ G.L. Ulmen, Carl Schmitt and Donoso Cortés, „Telos” 2003, 125, s. 69-79 


\section{RECEPTION DES PENSEES DE CARL SCHMITT AUX ETATS-UNIS APRES 1945}

\section{Résumé}

De nombreux chercheurs trouvent les inspirations schmittiennes dans la politique américaine contemporaine. Ce concept est autant paradoxal que Carl Schmitt lui-même traitait les États-Unis comme un État dont le système politique n'est pas bien préparé pour adopter une philosophie de décisionisme. Ses premiers travaux sur les États-Unis n'étaient pas aussi trop flatteurs. En utilisant la théorie de travelling concepts lancée par Mieke Bal, intellectuelle néerlandaise, l'article analyse la manière dont les idées de Carl Schmitt ont été implantées aux États-Unis. Nous avons indiqué que ce sont Hans Morgenthau et Leo Strauss qui les ont implantées sur le sol américain (le premier a utilisé la théorie de Schmitt pour décrire des relations internationales et l'autre a traduit sa théologie politique en philosophie politique). Nous avons aussi présenté des penseurs de gauche, rassemblés autour du magazine « Telos », qui ont lu Schmitt contre Schmitt. 